\title{
3 Research Square

\section{Nomogram for Single-pass Two-speed Automated Microkeratome Graft Preparation for Ultrathin Descemet Stripping Automated Endothelial Keratoplasty}

\author{
Álvaro Sánchez Ventosa \\ 5303-988X \\ Antonio Cano-Ortiz ( $\nabla$ antoniocanoortiz@gmail.com ) \\ Instituto de Oftalmología y Hospital La Arruzafa: Hospital La Arruzafa \\ Pablo Morales L. \\ Clinica Baviera Malaga \\ Timoteo González Cruces \\ Instituto de Oftalmología y Hospital La Arruzafa: Hospital La Arruzafa \\ Vanesa Ma Díaz Mesa \\ Instituto de Oftalmología y Hospital La Arruzafa: Hospital La Arruzafa \\ Alberto Villarrubia \\ Instituto de Oftalmología y Hospital La Arruzafa: Hospital La Arruzafa
}

Instituto de Oftalmología y Hospital La Arruzafa: Hospital La Arruzafa https://orcid.org/0000-0001-

\section{Research Article}

Keywords: microkeratome, ultrathin DSAEK, graft thickness, single-pass, speed

Posted Date: April 30th, 2021

DOI: https://doi.org/10.21203/rs.3.rs-475122/v1

License: (c) (i) This work is licensed under a Creative Commons Attribution 4.0 International License. Read Full License 


\section{Abstract}

\section{Purpose}

To create a nomogram including the translational speed of the microkeratome blade, microkeratome head size and precut tissue thickness to predict the postcut thickness for Descemet stripping automated endothelial keratoplasty (DSAEK) to obtain the thinnest possible graft.

\section{Methods}

This prospective study incorporated 48 grafts for DSAEK from March 2017 to June 2020. Corneal tissue for DSAEK was prepared by 3 experienced physicians using the Moria Evolution 3E (Moria Inc, Antony, France) microkeratome with 400, 450 and $500 \mathrm{~mm}$ head sizes. Precut central corneal thickness was measured with a DGH 550 handheld pachymeter (Pachette 2), taking an average of 3 readings. The microkeratome head was selected according to precut tissue thickness. The target donor lamella thickness ranged from 70 to $120 \mu \mathrm{m}$, and the selected microkeratome head size was $150 \mu \mathrm{m}$ less than the donor cornea thickness. Two translational speeds were used for the microkeratome cuts. One month after surgery, the central lenticular thickness was measured with a Visante ${ }^{\circledR}$ Optical Coherence Tomography caliper (Carl Zeiss Meditec Inc, Germany). A descriptive analysis was performed.

\section{Results}

Forty-eight donor grafts were prepared. Mean graft thickness was $97.58 \pm 29.84 \mu \mathrm{m}$ (range 39-176 $\mu \mathrm{m}$ ). Of the 48 samples, central graft thickness was $<120 \mu \mathrm{m}(81.3 \%)$ in $39,<100 \mu \mathrm{m}(58.3 \%)$ in 28 and $<80 \mu \mathrm{m}$ $(37.5 \%)$ in 18 at 1 -month follow-up. There were no statically significant differences between translational speeds.

\section{Conclusions}

A nomogram with an automated microkeratome to obtain thin grafts for DSAEK provided good graft thickness results without donor waste.

\section{Introduction}

Endothelial keratoplasty has become the standard of care for endothelial dysfunction due to rapid recovery of visual acuity, minimal postoperative refractive error and a low rejection rate.[1] Although Descemet membrane endothelial keratoplasty (DMEK) has gained popularity as it provides an anatomical replacement of the Descemet membrane and endothelium, it is nonetheless a more challenging surgical procedure that requires a steeper learning curve to master, making it less reproducible and limiting its indication to suitable cases. On the other hand, Descemet stripping automated endothelial keratoplasty (DSAEK) involves the replacement of dysfunctional endothelium with a donor disk consisting of endothelium, Descemet membrane and a thin section of donor stroma. DSAEK, together with DMEK, has become the gold standard for the management of Fuchs endothelial dystrophy, 
bullous keratopathy and penetrating keratoplasty graft failure. Due to the greater surgical complexity of DMEK, DSAEK plays a vital role in more complicated eyes with aniridia or important iris defects, glaucoma drainage devices, vitrectomy or anterior chamber intraocular lens.

Visual recovery with DSAEK, however, is usually slower and rejection rates higher when compared to DMEK. This is typically attributed to the fact that DSAEK grafts have a variable degree of stroma compared to DMEK. For this reason, in recent years the main objective in DSAEK graft preparation has been to achieve the thinnest possible lenticule, giving rise to the concept of ultrathin DSAEK (UT-DSAEK). [2]

The UT-DSAEK technique attempts to combine the benefits of DMEK and DSAEK: the rapid visual recovery and low rejection rates of DMEK and the reproducibility of DSAEK. To date, ultra-thin lamellar grafts have been considered to be those with a central graft thickness between 100 and $130 \mu \mathrm{m}$.[3] Multiple techniques have been described to achieve this goal: simple nomograms,[4] double-pass microkeratome cuts,[5, 6] stromal thinning by directing sterile airflow,[7] use of polyvinyl alcohol or cellulose sponges[8] or placing the tissue in hyperosmotic tissue medium[9] before tissue preparation, combinations of femtosecond[10] and/or excimer laser[11] and varying artificial anterior chamber (AAC) pressure.[12] Nevertheless, not all of these techniques reliably produce ultrathin tissue and may result in tissue loss (button hole, decrease of endothelial cells), increase tissue preparation time and add substantial financial costs.

The purpose of this study was to develop a nomogram for DSAEK using the Moria microkeratome incorporating two translational speeds, blade holder size and corneal thickness to consistently achieve ultrathin endothelial donor lamellae between 70 and $120 \mu \mathrm{m}$.

\section{Material And Methods}

In this prospective single-center case series, 48 patients scheduled to undergo DSAEK surgery were enrolled from March 2017 to June 2020 in order to develop a nomogram based on the single-pass rotational microkeratome (Moria Inc, Antony, France). All patients were recruited and managed in the Cornea Department at Instituto de Oftalmología la Arruzafa (Córdoba, Spain). Written informed consent

was obtained from all the patients after the nature of the study was explained. The study adhered to the tenets of the Declaration of Helsinki and was approved by the clinic's institutional ethics committee. Included in the study were subjects of either sex, age 18 years or older, with a diagnosis of Fuchs endothelial dystrophy (FECD) or pseudophakic bullous keratopathy.

All the patients underwent a complete preoperative ophthalmic examination including evaluation of uncorrected and corrected distance visual acuity, manifest refraction, slit lamp biomicroscopy, Goldmann applanation tonometry, funduscopy, optical coherence tomography and B-scan ultrasonography when required. 
The donor corneas were supplied by the Barcelona Tissue Bank, Spain. Baseline donor endothelial cell densities were measured by bank technicians using specular microscopy. A graft thickness $<100 \mu \mathrm{m}$ was targeted. Graft thickness was measured at the 1-month ophthalmological examination using the Visante® optical coherence tomography caliper (Carl Zeiss Meditec Inc, Germany) (Fig. 1).

\section{Surgical technique}

In the operating room, the donor cornea was removed from the culture medium and mounted on the AAC of the automated lamellar therapeutic keratoplasty (ALTK) system (Moria, SA, Antony, France). The AAC was linked to a phacoemulsification unit with a Venturi pump with the hydrostatic pressure set at 30 $\mathrm{mmHg}$, using a balanced salt solution bottle hung at a fixed height above the work area maintaining constant internal pressure.

Before starting the dissection, the central corneal thickness was measured with a DGH 550 handheld ultrasonic pachymeter (Pachette 2). Serial pachymetry measurements were taken to have a consistent estimate. The cornea was prepared by removing the epithelium using eye spears moistened with balanced salt solution. Based on the nomogram, the surgeons chose the microkeratome cutting head according to the pachymetry measurements with a gap of 400,450 or $500 \mu \mathrm{m}$, aiming for a graft thickness between 80 and $100 \mu \mathrm{m}$. For donor corneal thicknesses between 510 and $559 \mu \mathrm{m}$, the 400- $\mu \mathrm{m}$ blade holder was used, for thickness between 560 and $609 \mu \mathrm{m}$, the $450-\mu \mathrm{m}$ blade holder and for thicknesses between 610 and $660 \mu \mathrm{m}$ the $500-\mu \mathrm{m}$ blade holder. Either speed 1 or 2 was used randomly in the microkeratome blade following the indications below. The cutting head was attached to the hand piece with the MORIA Evolution 3E microkeratome (MORIA, Antony, France) using an automated linear system. The pressure was increased to $110 \mathrm{~cm} \mathrm{H}_{2} \mathrm{O}$ and checked with a 65-mmHg Barraquer tonometer. The donor cornea was cut with a single pass and irrigated with balanced salt solution during the entire process.

After microkeratome cutting, the AAC pressure was reduced to $30 \mathrm{mmHg}$ to minimize the period of high pressure on the cornea. Eight sterile ink marks were placed at equidistant points on the graft bed edge to facilitate lenticule trephination by the surgeon. The anterior stromal cap was set over the graft and the AAC was filled with air to prevent cornea collapse. Once the free cap was created, the anterior and posterior lamellae were placed together over the punch system with the endothelial layer facing up. The donor disks were punched between $6.50 \mathrm{~mm}$ and $8.50 \mathrm{~mm}$ in all cases, depending on the recipient corneal diameter. Surgery was completed as per the standard technique used at the clinic.[13]

\section{Results}

The study enrolled 48 eyes of 47 patients. The mean precut donor tissue thickness was $620 \pm 0.73 \mu \mathrm{m}$ (range 658 to $510 \mu \mathrm{m}$ ). One month postoperatively, the mean donor graft thickness was $97.58 \pm 29.84 \mu \mathrm{m}$ (range 39 to $176 \mu \mathrm{m}$ ). 
In 20 corneas, speed 1 was used, attaining a mean precut donor tissue thickness and a mean donor graft thickness of $609.81 \pm 44.95 \mu \mathrm{m}$ and $93.57 \pm 31.20 \mu \mathrm{m}$, respectively. In the remaining 28 corneas, in which speed 2 was used, the mean precut donor tissue thickness and mean donor graft thickness was $582.13 \pm$ $44.89 \mu \mathrm{m}$ and $102.83 \pm 34.93 \mu \mathrm{m}$, respectively Comparison of the means of both speeds with Student's $t$ test showed a non-significant difference of $9.26 \mu \mathrm{m}$.

Three microkeratome heads were selected using the nomogram previously described according to the pachymetry values. For the 400,450 and $500 \mu \mathrm{m}$ blade heads, similar graft thicknesses of $103.50 \pm 33.46$ $\mu \mathrm{m}, 97.48 \pm 29.47 \mu \mathrm{m}$ and $92.31 \pm 28.37 \mu \mathrm{m}$, respectively, were obtained (Table 1).

Table 1

Nomogram for ultrathin grafts for DSAEK using an automated microkeratome.

\begin{tabular}{|lllllll|}
\hline $\begin{array}{l}\text { Corneal thickness } \\
(\mu \mathrm{m})\end{array}$ & $\begin{array}{l}\text { Blade head size } \\
(\mu \mathrm{m})\end{array}$ & $\begin{array}{l}\text { Eyes } \\
(\mathrm{n})\end{array}$ & & \multicolumn{2}{l}{$\begin{array}{l}\text { Precut tissue thickness } \\
(\mu \mathrm{m})\end{array}$} & Graft thickness $(\mu \mathrm{m})$ \\
\cline { 4 - 6 } & & & Mean & $\begin{array}{l}\text { Standard } \\
\text { deviation }\end{array}$ & Mean & $\begin{array}{l}\text { Standard } \\
\text { deviation }\end{array}$ \\
\hline $\begin{array}{l}510-559(512.6- \\
562.5)\end{array}$ & 400 & 12 & 539.58 & 11.54 & 103.50 & 33.46 \\
\hline $\begin{array}{l}560-610(562.6- \\
612.5)\end{array}$ & 450 & 23 & 591.61 & 13.28 & 97.48 & 29.47 \\
\hline $\begin{array}{l}610-660(612.6- \\
662.5)\end{array}$ & 500 & 13 & 645.31 & 17.80 & 92.31 & 28.37 \\
\hline
\end{tabular}

Finally the chi-square test was carried out to evaluate whether there was a difference between the observed and expected (actual cut at one month vs. estimated cut). As the statistical value was higher than the critical value, the test of independence was rejected and an association was therefore considered to exist between the observed and the expected values at $95 \%$.

\section{Discussion}

Since Melles introduced the first successful approach to posterior lamellar keratoplasty in 1998, endothelial keratoplasty has rapidly gained surgical preference over penetrating keratoplasty. The first report of precut DSAEK tissue was published in 2008 by Chen et al.,[14] who achieved a mean graft thickness of $169 \pm 36 \mu \mathrm{m}$. Since then, numerous techniques have been described to achieve reliable and reproducible graft lenticule thickness, targeting visual acuities comparable to DMEK. Aside from singleand double-pass nomograms, the most recent techniques to thin the cornea before the microkeratome pass include swelling the stroma for 60 seconds with a balanced salt solution[15] or drying with polyvinyl alcohol or cellulose sponges,[9, 12] increasing the AAC pressure[12] or directing sterile airflow over the exposed stroma.[7] 
While DMEK has been used for ideal cases with high visual acuity potential because it offers faster recovery and a lower rejection rate,[16] DSAEK is now generally reserved for eyes with ocular comorbidities. In this study, most of the patients undergoing surgery presented associated conditions such as glaucoma, ocular perforating and penetrating injuries, or retinal detachment or corneal scarring, in which the aim of surgery was to relieve the pain of bullous keratopathy, not to achieve good visual acuity due to stromal fibrosis. The focus of this study was therefore not best corrected visual acuity.

In this study, a nomogram for DSAEK was created using a single-pass technique in which the targeted graft thickness 1-month after surgery below $120 \mu \mathrm{m}$ was achieved in $81.25 \%$ of the cases (39 eyes). Twenty eight eyes (58.33\%) had a central graft thickness less than $100 \mu \mathrm{m}$, and 18 eyes $(37.50 \%)$ had a central graft thickness below $80 \mu \mathrm{m}$. Considering that the swelling process resolves in 3 to 6 months, if these grafts had been measured at the 6-month follow-up most graft thicknesses would have been included in the UT-DSAEK category. Romano et al.[9] published a case series of 10 corneas in which a decrease was seen in the graft thickness from the time it was cut until 3 months of up to $38 \%$. These changes have also been reported in other studies in which graft thinning occurred up to 3 months,[9, 17] 6 months $[18,19]$ and even 1 year[20] after DSAEK. We preferred to measure donor graft thickness at the 1month follow-up as most of the patients did not live in the proximity of the clinic and could not return for an appointment at 6 months. Only 9 of the 48 lamellae were thicker than $120 \mu \mathrm{m}$, indicating the reproducibility of the procedure. Most authors describe variability in graft thickness, and the standard deviation $\geq 33 \mu \mathrm{m}$ reported here is very similar to that of other studies.[20-22]

In contrast to the assertion of Cheung et al.,[23] that deep microkeratome cuts produce more variability in cut depth than shallow cuts, we achieved thinner graft thicknesses using microkeratome heads with a thicker blade (Table 1). We believe this variability may be associated with the preservation medium used for the donor cornea. Fresh corneas and corneas stored at $4^{\circ} \mathrm{C}$ do not undergo the swelling process as do cultured corneas and may vary substantially in thickness measured the time of surgery. Among the different corneal preservation media, there is some variability depending on preservation time. In a recent study involving seventeen pairs of donor corneas, two preservation media, Optisol-GS and Cornea Cold, were compared, showing a mean thickness at day 7 of $644 \mathrm{~mm}$ in the Cornea Cold group and $591 \mathrm{~mm}$ in the Optisol GS group. This gap was reduced after 21 days of storage, when the mean thickness was 714 $\mathrm{mm}$ in the Cornea Cold group and $708 \mathrm{~mm}$ in the Optisol GS group.[24] Thus, although the same nomogram could be used, small adjustments to hydration status or tissue consistency should be applied to avoid perforation.

The Moria microkeratome has been used and studied in different articles reporting lenticule thicknesses of $63 \pm 29 \mu \mathrm{m}$ at 5 months,[4] $69.9 \pm 20.8 \mu \mathrm{m}$ at 3 months[9] and $89.4 \pm 26.2 \mu \mathrm{m}$ at 6 months.[25] However, most of these studies used the double-pass microkeratome technique,[8, 25, 26] which involves significant risk for perforation, endothelial cell loss and stromal surface irregularity. Other studies have used a single $350 \mu \mathrm{m}$ blade head in 10 corneas,[9] a combination of femtosecond[10] or a manual rotation system. $[10,26]$ In our study, we assessed the variable of microkeratome cutting speed, confirming that there was no variation with respect to the fast or slow speed. This does not occur with 
other microkeratomes such as the automated Amadeus II, which uses a head advancement speed of 3.0, 2.0 and $1.5 \mathrm{~mm} / \mathrm{sec}$ and achieves statistically significant results with mean graft thicknesses one month postoperatively of $99.33 \pm 16.97 \mu \mathrm{m}$.[13]

The limitations of this study are the relatively small sample size and the short follow-up period. The short follow-up was unavoidable as many of the patients were not local to the clinic and could not return for an appointment at 3-6 months. For this reason, we did not extend the follow up period as this would have resulted in a significant dropout rate. The major limitation of microkeratome dissection may be its poor accuracy in determining the final thickness of the dissected tissue, especially when preparing grafts for UT-DSAEK. This nomogram succeeded in $81.25 \%$ of the cases in achieving a graft thickness below 120 $\mu \mathrm{m}$, taking into consideration that had the measurement been performed at 3 months, the number of cases below $120 \mu \mathrm{m}$ would have been higher. This nomogram can be further refined by including additional variables (i.e., storage medium, AAC pressure, drying or swelling process).

In conclusion, using an automated microkeratome with a customized single-pass nomogram allows ultrathin grafts with reduced variability in thickness to be obtained. Only a single pass is required, reducing the risk of donor graft damage or waste. No complications were encountered during flap preparation with this technique.

\section{Declarations}

\section{Funding}

This study was not funded by any institution or organization or any other funding body.

\section{Compliance with ethical standards}

\section{Conflict of interest}

All authors declare no conflict of interest with any of the stated materials in the study.

\section{Ethical approval}

All procedures performed in studies involving human participants were in accordance with the ethical standards of the institutional and/or national research committee and with the 1964 Helsinki declaration and its later amendments or comparable ethical standards.

\section{Informed consent}

Informed consent was obtained from all individual participants included in the study.

There is no Conflict to disclose.

\section{References}


1. Lee WB, Jacobs DS, Musch DC, et al (2009) Descemet's Stripping Endothelial Keratoplasty: Safety and Outcomes. A Report by the American Academy of Ophthalmology. Ophthalmology 116:18181830. https://doi.org/10.1016/j.ophtha.2009.06.021

2. Hsu M, Hereth WL, Moshirfar M (2012) Double-pass microkeratome technique for ultra-thin graft preparation in Descemet's stripping automated endothelial keratoplasty. Clin Ophthalmol 6:425-432. https://doi.org/10.2147/OPTH.S29479

3. Busin M, Madi S, Santorum P, et al (2013) Ultrathin descemet's stripping automated endothelial keratoplasty with the microkeratome double-pass technique: Two-year outcomes. Ophthalmology 120:1186-1194. https://doi.org/10.1016/j.ophtha.2012.11.030

4. Nahum Y, Leon P, Busin M (2015) Postoperative graft thickness obtained with single-pass microkeratome-assisted ultrathin descemet stripping automated endothelial keratoplasty. Cornea 34:1362-1364. https://doi.org/10.1097/ICO.0000000000000603

5. Kanavi MR, Chamani T, Kheiri B, Javadi MA (2018) Single versus double pass technique for preparation of ultrathin Descemet's stripping automated endothelial keratoplasty tissues from donated whole eyes. Cell Tissue Bank 19:623-628. https://doi.org/10.1007/s10561-018-9712-3

6. Sikder S, Nordgren RN, Neravetla SR, Moshirfar M (2011) Ultra-thin donor tissue preparation for endothelial keratoplasty with a double-pass microkeratome. Am J Ophthalmol 152:202-208.e2. https://doi.org/10.1016/j.ajo.2011.01.051

7. Thomas PBM, Mukherjee AN, O'Donovan D, Rajan MS (2013) Preconditioned donor corneal thickness for microthin endothelial keratoplasty. Cornea 32:173-178. https://doi.org/10.1097/ICO.0b013e3182912fd2

8. Bucher F, Roters S, Mellein A, et al (2013) OSMO-UT-DSAEK using THIN-C medium. Graefe's Arch Clin Exp Ophthalmol 251:2181-2185. https://doi.org/10.1007/s00417-013-2434-0

9. Romano V, Steger B, Myneni J, et al (2017) Preparation of ultrathin grafts for Descemet-stripping endothelial keratoplasty with a single microkeratome pass. J Cataract Refract Surg 43:12-15. https://doi.org/10.1016/j.jcrs.2016.12.009

10. Murta JN, Rosa AM, Quadrado MJC, et al (2013) Combined use of a femtosecond laser and a microkeratome in obtaining thin grafts for Descemet stripping automated endothelial keratoplasty: An eye bank study. Eur J Ophthalmol 23:584-589. https://doi.org/10.5301/ejo.5000273

11. Thannhäuser $\mathrm{CL}$, Palka $\mathrm{K}$, Herbst $\mathrm{H}$, et al (2014) Mikrokeratom- und Excimer-Laser-gestützte endotheliale Keratoplastik (MELEK). Klin Monbl Augenheilkd 231:1008-1011. https://doi.org/10.1055/s-0034-1383094

12. Romano V, Steger B, Chen JY, et al (2015) Reliability of the Effect of Artificial Anterior Chamber Pressure and Corneal Drying on Corneal Graft Thickness. Cornea 34:866-869. https://doi.org/10.1097/IC0.0000000000000451

13. Villarrubia A, Cano-Ortiz A (2015) Development of a nomogram to achieve ultrathin donor corneal disks for Descemet-stripping automated endothelial keratoplasty. J Cataract Refract Surg 41:146151. https://doi.org/10.1016/j.jcrs.2014.04.036 
14. Chen ES, Terry MA, Shamie N, et al (2008) Precut Tissue in Descemet's Stripping Automated Endothelial Keratoplasty. Donor Characteristics and Early Postoperative Complications. Ophthalmology 115:497-502. https://doi.org/10.1016/j.ophtha.2007.11.032

15. Farbman NH, Y Li J, Ling J, et al (2019) A Simple 60-Second Swelling Technique for More Consistent Ultrathin DSAEK Graft Preparation. Cornea 38:1209-1214. https://doi.org/10.1097/IC0.0000000000002048

16. Deng SX, Lee WB, Hammersmith KM, et al (2018) Descemet Membrane Endothelial Keratoplasty: Safety and Outcomes: A Report by the American Academy of Ophthalmology. Ophthalmology 125:295-310. https://doi.org/10.1016/j.ophtha.2017.08.015

17. Bae SS, Menninga I, Hoshino R, et al (2018) Nomogram to Predict Graft Thickness in Descemet Stripping Automated Endothelial Keratoplasty: An Eye Bank Study. Cornea 37:687-690. https://doi.org/10.1097/IC0.0000000000001524

18. Madi S, Leon P, Nahum Y, et al (2019) Five-Year Outcomes of Ultrathin Descemet Stripping Automated Endothelial Keratoplasty. Cornea 38:1192-1197. https://doi.org/10.1097/IC0.0000000000001999

19. Pogorelov P, Cursiefen C, Bachmann BO, Kruse FE (2009) Changes in donor corneal lenticule thickness after Descemet's stripping automated endothelial keratoplasty (DSAEK) with organcultured corneas. Br J Ophthalmol 93:825-829. https://doi.org/10.1136/bjo.2008.147389

20. Dimitry MES, Lewis AD, Zacharaki F, et al (2017) Simple Single-Pass Technique for Ultrathin Descemet Stripping Automated Endothelial Keratoplasty: A Pilot Study. Cornea 36:1178-1183. https://doi.org/10.1097/IC0.0000000000001273

21. Busin M, Madi S, Santorum P, et al (2013) Ultrathin descemet's stripping automated endothelial keratoplasty with the microkeratome double-pass technique: Two-year outcomes. Ophthalmology 120:1186-1194. https://doi.org/10.1016/j.ophtha.2012.11.030

22. Roberts HW, Mukherjee A, Aichner H, Rajan MS (2015) Visual outcomes and graft thickness in microthin DSAEK - One-year results. Cornea 34:1345-1350.

https://doi.org/10.1097/IC0.0000000000000596

23. Cheung AY, Hou JH, Bedard P, et al (2018) Technique for Preparing Ultrathin and Nanothin Descemet Stripping Automated Endothelial Keratoplasty Tissue. Cornea 37:661-666. https://doi.org/10.1097/ICO.0000000000001510

24. Ho JW, Jung H, Chau M, et al (2020) Comparisons of Cornea Cold, a New Corneal Storage Medium, and Optisol-GS. Cornea 39:1017-1019. https://doi.org/10.1097/IC0.0000000000002330

25. Saunier V, Robinet Perrin A, Costet C, Touboul D (2016) Reproductibilité de la simple découpe pour la préparation des DSAEK avec le microkératome MORIA à usage unique. J Fr Ophtalmol 39:780-785. https://doi.org/10.1016/j.jfo.2016.06.004

26. Waite A, Davidson R, Taravella MJ (2013) Descemet-stripping automated endothelial keratoplasty donor tissue preparation using the double-pass microkeratome technique. J Cataract Refract Surg 39:446-450. https://doi.org/10.1016/j.jcrs.2012.10.048 


\section{Figures}

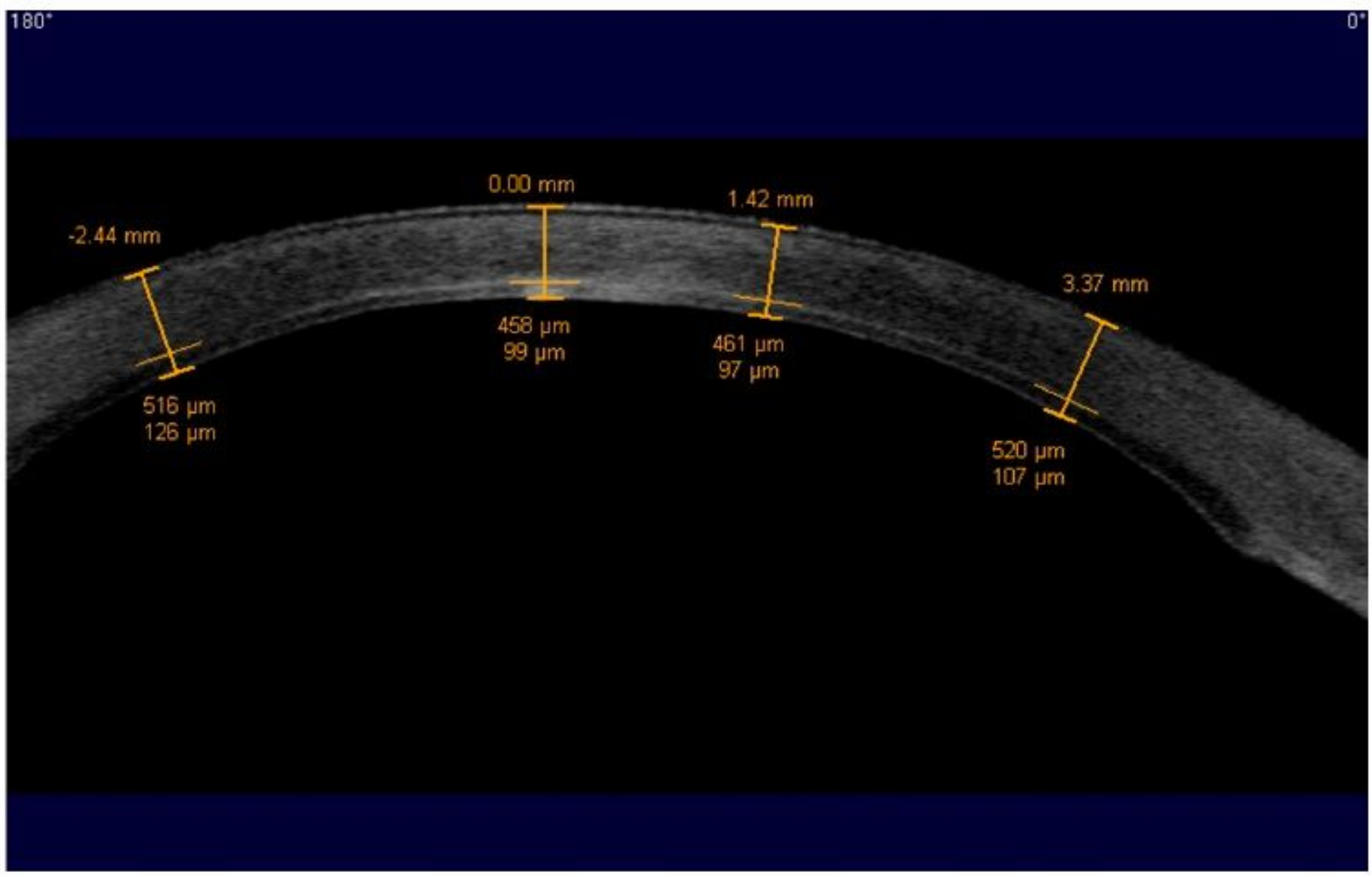

\section{Figure 1}

Example of an ultrathin donor lamella measured with Visante's caliper 